University at Buffalo School of Law

Digital Commons @ University at Buffalo School of Law

Journal Articles

Faculty Scholarship

Spring 2007

\title{
The Place of Translation in Jerusalem's Criminal Trial Court
}

Irus Braverman

University at Buffalo School of Law

Follow this and additional works at: https://digitalcommons.law.buffalo.edu/journal_articles

Part of the Comparative and Foreign Law Commons, and the Criminal Law Commons

\section{Recommended Citation}

Irus Braverman, The Place of Translation in Jerusalem's Criminal Trial Court, 10 New Crim. L. Rev. 239 (2007).

Available at: https://digitalcommons.law.buffalo.edu/journal_articles/329

Published as Irus Braverman, The Place of Translation in Jerusalem's Criminal Trial Court, 10 New Crim. L. Rev. 239 (2007). (C) 2007 by the Regents of the University of California. Copying and permissions notice: Authorization to copy this content beyond fa

\section{IN COPYRIGHT}

This Article is brought to you for free and open access by the Faculty Scholarship at Digital Commons @ University at Buffalo School of Law. It has been accepted for inclusion in Journal Articles by an authorized administrator of Digital Commons @ University at Buffalo School of Law. For more information, please contact lawscholar@buffalo.edu. 


\section{THE PLACE OF TRANSLATION IN JERUSALEM'S CRIMINAL TRIAL COURT}

Irus Braverman*

If I translate the words the defendant will really be lost ${ }^{1}$

But nothing's lost. Or else: all is translation and every bit of us is lost in it. ${ }^{2}$

The court-appointed translator is largely an invisible actor in the legal space. The Israeli context provides an extreme example of this invisibility: apart from a general statutory definition of the court's obligation to translate criminal proceedings, the work of translation in the Israeli courtroom is mostly unregulated by state law, rendering it highly susceptible to informal manifestations. This article offers a critical empirical investigation into the micropractices of translation performed in the Jerusalem criminal trial court in 2002. On the face of things, the court-appointed translator performs a technical task in the everyday working of the court. Expected to mediate between the defense, the prosecution, and the judiciary, the translator is usually not perceived as an active participant in the legal procedure. Problematizing this perception, the article examines the multiple tasks of court-appointed translators in the

*Associate, Harvard University Humanities Center; SJD Candidate, University of Toronto School of Law; M.A. in Criminology, the Hebrew University of Jerusalem; LL.B. (Law) the Hebrew University of Jerusalem. I wish to thank Duncan Kennedy, Lucie White, Joe Hermer, Hanina Ben Menachem, Mariana Valverde, and David Schneiderman for their insightful comments on earlier drafts. Unless otherwise noted, all translations of the interviews cited herein are my own.

I. Interview with Ali, Court-Appointed Translator, Jerusalem Criminal Trial Court, in Jerusalem (October, 2002). All of the informants in this study are referred to by pseudonyms.

2. James Merrill, Lost in Translation, in Divine Comedies Io (1977).

New Criminal Law Review, Vol. 10, Number 2, pps 239-277. ISSN 1933-4192, electronic ISSN 1933-4206. (C) 2007 by the Regents of the University of California. All rights reserved. Please direct all requests for permission to photocopy or reproduce article content through the University of California Press's Rights and Permissions website, http://www.ucpressjournals. com/reprintInfo.asp. DOI: 10.1525/nclr.2007.IO.2.239. 
Jerusalem criminal trial court, thereby challenging traditional court roles and legal perceptions. Not exactly court officials yet also not outsiders to the courtroom, the translators exercise a mixed bag of formal and substantive roles. They act not only as linguistic intermediaries, but also as intermediaries between formal legalities and commonsense discourses.

The article is divided into three parts. The first part sketches three primary linguistic challenges, as those are identified by the translators interviewed for this study. The second part of the article adds the perspective of other court practitioners so as to depict a dynamic picture of the particular loyalties of the translators. Finally, the third part of the article examines the liminal, "third space, "of translation. Precisely for its extreme articulation of sovereign ideologies, the Israeli/Palestinian setting provides an intriguing geobistorical context within which to think about translation. This last part ties the article together by highlighting the dynamic relationship between language, law, and space, as these are constructed and subverted through practices of translation within the particular setting of the Jerusalem courtroom.

\section{INTRODUCTION}

On the face of things, the court-appointed translator performs a technical task in the everyday working of the court. Expected to mediate between the defense, the prosecution, and the judiciary, the translator is usually not perceived an active participant in the legal procedure: "they have no legal voice of their 'own' but rather give voice to others". ${ }^{3}$ Susan Berk-Seligson endorses such an approach, stating that "ideally, [the translator] should not exist as a distinct verbal participant in [her] own right during the course of a judicial proceeding. In effect, [she] is meant to speak solely in place of the other participants in the courtroom, those considered to legitimately hold the right to speak: the attorneys, witnesses, [prosecutors], and the judge."

3. See Lisa Hajjar, Courting Conflict: The Israeli Military Court System in the West Bank and Gaza 147 (2005).

4. Susan Berk-Seligson, The Bilingual Courtroom: Court Interpreters in the Judicial Process with a New Chapter 54 (2d ed. 2002). Contrary to Berk-Seligson's empirical observation 
"Who is the translator, then?" wonders James Boyd White, and immediately clarifies: "I don't mean the practicing bureaucrat, moving from one technical language to another, but the person who wishes to connect two worlds." Conversely, this article will focus precisely on this "practicing bureaucrat"-the court-appointed translator-positing him as both the connector and the differentiator between the complexities of the court wor(l)ds. The identity and tasks of the court-appointed translators and their relationships with other court practitioners and users will be explored herein through an interpretive analysis ${ }^{6}$ of fifteen semi-structured interviews ${ }^{7}$ conducted between May and October 2002 with actors that perform various official roles in Jerusalem's criminal trial court, mostly court-appointed translators, and also judges, prosecutors, and defense attorneys. ${ }^{8}$

Who is the trial court translator, then? Through problematizing the frequent perception of the translator as performing only a technical, "voiceless voice" role, this article examines the multiple tasks of the court-appointed translator in the Jerusalem criminal trial court in 2002. The article's focus on the task of the translator in the trial court, rather than in any other

that translators tend to be women, id. at 293 , in the Jerusalem court the translators are mostly men, hence my decision to use the masculine gender when referring to the cranslator, although in some sense one could develop the idea that the linguistic act of translation is structurally linked to what Hélène Cixous calls écriture féminine. See Hélène Cixous, The Laugh of the Medusa, I Signs 875 (Keith Cohen \& Paula Cohen trans., 1976).

5. See James Boyd White, Justice as Translation: An Essay in Cultural and Legal Criticism 23I (1990) (emphasis added).

6. See Clifford Geertz, Local Knowledge: Further Essays in Interpretive Anthropology (1983); Christine B. Harrington \& Barbara Yngvesson, Interpretive Sociolegal Research, is Law \& Soc. Inquiry 135 (1990).

7. I also observed approximately half a dozen trials and daylong arrest proceedings for this purpose. In addition, during my work as a criminal prosecutor at the Jerusalem criminal trial court between 1995 and 1997 , I was exposed to at least one hundred translation instances. This personal encounter introduced me to both the centrality and marginality of translation in the Jerusalem court setting and triggered my attention to the potential insights that this sort of critical empirical study might provide.

8. I was unable to interview defendants for this study, mostly for "security" reasons. In most cases I observed, the defendants were brought to the court handcuffed and were constantly guarded. This prevented any close communication with them. The situation that supposedly called for these extra security measures will be discussed herein. 
court setting, is part of what may be characterized as a sociolegal tradition of investigation into this particular court system. The work on trial courts of Susan Silbey, ${ }^{9}$ Sally Merry, ${ }^{10}$ Lucie White," Austin Sarat, ${ }^{12}$ Barbara Yngvesson, ${ }^{13}$ and Lisa Hajjar ${ }^{14}$ addresses this court's centrality for the everyday working of the law, along with its marginality within the traditional legal discourse, which is typically more interested in the working of the supreme court. ${ }^{15}$ But while the marginality of trial courts within the judicial system might be depicted as a sign of powerlessness, it is at the same time also a form of power: removed from the center of attention, trial courts exercise fluid notions of legality and invent various hybrids of formal and informal practices. ${ }^{16}$ Although the study of trial courts has generated fascinating insights into the everyday working of the law, ${ }^{17}$ not much has been written within this tradition about the particular task of

9. See Susan Silbey, Making Sense of the Lower Courts, 6 Just. Sys. J. 13 (198I).

Io. See Sally Engle Merry, Everyday Understandings of the Law in Working-Class America, 13 Am. Exhnologist 253 (1986).

II. See Lucie White, To Learn and Teach: Lessons from Driefontein on Lawyering and Power, Wis. L. Rev. 699 (1988).

12. See Austin Sarat, Rhetoric and Remembrance: Trials, Transcription, and the Politics of Critical Reading, 23 Legal Stud. F. 355 (1999) [hereinafter Sarat, Rhetoric and Remembrance]; Austin Sarat, Understanding Trial: A Critique of Social Science Approaches, 6I Judicature 318 (1978) [hereinafter Sarat, Understanding Trial].

13. See Barbara Yngvesson, Making Law at the Doorway: The Clerk, the Court, and the Construction of Community in a New England Town, 22 Law \& Soc'y Rev. 409 (1988).

14. See Hajjar, supra note 3. In particular, Hajjar focuses on Israeli military courts in the occupied Palestinian territories.

I5. The insistence of Critical Legal Studies (CLS) to focus mainly on supreme court cases has been the focus of much criticism by certain law and society approaches. See, e.g., David M. Trubek \& John Esser, Critical Empiricism, in American Legal Studies: Paradox, Program, or Pandora’s Box? I4 Law \& Soc. Inquiry 3 (1989); David M. Trubek, Where the Action Is: Critical Legal Studies and Empiricism, 36 Stan. L. Rev. 575 (1984).

I6. See Merry, supra note io.

17. However, the new legal pluralism approach asserts that "not all law takes place in the court," hence diverting the attention away from this traditional legal space. See Sally Engle Merry, Legal Pluralism, 22 Law \& Soc'y Rev. 869, 874 (1988). While drawing on this literature, this article nonetheless shifts the attention back into the courtroom so as to show how, in the heart of law's empire, state law never establishes absolute power. Such slippages in the sovereignty of state law will be examined throughout the article. See also Austin Sarat \& Jonathan Simon, Beyond Legal Realism? Cultural Analysis, Cultural Studies, and the Situation of Legal Scholarship, I3 Yale J.L. \& Human. 3, 22 (200I). 
the translator in the trial court setting. ${ }^{18}$ Also, to the best of my knowledge this is the first sociolegal study that focuses on Israeli trial courts in general, and on the task of court translators in this serting in particular. ${ }^{19}$

The article is divided into three parts. The first part of the arricle (section I) sketches three primary linguistic challenges, as identified by the translators themselves. Although at first they seem technical, it soon becomes clear that these linguistic challenges are aspects of the translator's interrelations with other court practitioners. In particular, it becomes evident that the act of translation is also a declaration of loyalty by the translators. Because of their particular task, the task of translation, and their specific roles in the Jerusalem criminal trial court, the translators oscillate berween their loyalty to court users, especially defendants and witnesses, and their official loyalty to the court, especially judges.

This article's focus on the loyalties of the translators in their everyday court practices illuminates the task of translation as one that, although conceived as solely mechanical, also engages highly normative decisions. The second part of the article (section II) expands on the theme of loyalty by exploring it through the prism of the translators' relationships with other, perhaps more Hermes-type court figures, especially defense lawyers and judges. Manifesting in various forms, the hybrid tasks of the translators challenge traditional court roles and legal perceptions, making it possible to see them in a different light. For example, the complex relationship between translators and defense lawyers both blurs and reconstitures the supposed boundaries between these professions.

The invisibility in state law of the translators, who are not exactly court officials yet also not outsiders to the courtroom, ${ }^{20}$ also manifests in their transparency within the legal proceedings that take place in the Israeli courts. Indeed, except for a few sections in the Israeli law of criminal procedure that define the court's general obligation to translate criminal trial proceedings,

18. Berk-Seligson and Conley and O'Barr are two of the few exceptions. See BerkSeligson, supra note 4; John M. Conley \& William M. O’Barr, Just Words: Law, Language, and Power (1988).

19. Although addressing many similar themes, Lisa Hajjar's work focuses on military courts in the occupied territories. Conversely, the Jerusalem trial court, which serves as the focus of this study, is (arguably) located in the State of Israel. Whether this geographic distinction carries any actual weight will be addressed in the third part of the arricle (section III). See Hajjar, supra note 3.

20. See Merry, supra note Io, at 266. 
the practices of court-appointed translators have remained completely unregulated by state law, leaving these practices to take shape through informal devices. This (formally) unregulated space is an excellent breeding ground for multiple forms of ordering, both replications of state law and non-state legal norms. ${ }^{21}$ Finally, the translators exercise a mixed bag of formal and substantive roles, hybrids of dominant and local ideologies. They act not only as linguistic intermediaries, in the narrow sense of this term, but also as intermediaries between formal legality and commonsense discourses.

At a certain point, an inevitable question infiltrates into the informants' narratives: does the act of translation by court-appointed translators actually make a difference? Some of the informants perceive the task of translation as crucial for the production of meaning in a courtroom setting. They present at least two examples that illustrate the effects of translation on legal procedure: one regards the translator's discretion to choose certain meanings rather than others; the other regards the intentional intervention of the translators in the words of the defendants.

However, other informants present a somewhat more skeptical account of the importance of court translation. The trial judges, for example, have questioned the relevancy of the defendants' words, suggesting instead that their body language reveals all there is to know on the matter. Moreover, although a literal interpretation of formal law implies a two-directional translation procedure, the practices described by the various informants depict a one-sided procedure, whereby the translators make the words of court users understandable only to court practitioners, and especially to judges. This skepticism on the part of the judges towards literal words, as well as the one-sidedness of the translation act, end up reinforcing the juridical powers practiced by the judges, while also eroding common principles of due process. Consequently, more than rendering the act of translation as meaningless, it can also be considered as concealing the subtle work of law, which is highly self-absorbed and hegemonic.

Finally, still within an empirical investigation into micro rather than macro encounters, the third part of the article (section III) examines the liminal "third space" 22 of translation. Precisely for its extreme articulation

2I. For a discussion of multiple forms of ordering, see Peter Fitzpatrick, Law and Socieries, 22 Osgoode Hall L.J. IIs (1984).

22. I use the term space to simultaneously imply materiality and sociality. See also Henri Lefebvre, The Production of Space (Donald Nicholson Smith trans., 199r). 
of sovereign ideologies, the Israeli/Palestinian setting provides an intriguing geohistorical context within which to think about translation. Accordingly, this section stresses the dialectic and dynamic relationship between language, law, and space, as these are constructed and subverted through practices of translation within the particular setting of the Jerusalem courtroom. The narrative of Ali, one of the translators interviewed for this project, provides particular insights into the ethno-political role of translation, especially in his role as a Palestinian-Israeli translator who operates in between the wor(l)ds at a time and space of conflict. Drawing mostly on Lisa Hajjar's book Courting Conflict, this last section suggests that the act of translation, as practiced within the Jerusalem criminal trial court, acutely demonstrates and reinforces the thin boundaries between the operations of civil and military courts in this place.

\section{THE MEANING-MAKING POWERS OF TRANSLATION: THREE LINGUISTIC CHALLENGES}

\section{A. Court-Appointed Translators: An Introduction}

The need for court translation is usually ascribed to the simple fact that the court's various participants do not always speak or understand the same language. ${ }^{23}$ The assumption that underlies this act is that it is unjust to judge someone who does not understand the language in which the law is inscribed or the judgment pronounced. ${ }^{24}$

Accordingly, section 140 of the 1982 Israeli Law of Criminal Procedure states that "[w]here it appears to the court that the accused does not know Hebrew, it shall appoint a translator for him or itself act as a translator." ${ }^{25}$ According to section I4I, any evidence presented before the court must be

23. Similarly, Lisa Hajjar says this about the function of translators in military courts in the occupied territories: "[t] he use of Arabic-Hebrew translators in this court system is essential to its functioning because of the simple fact that many Palestinians from the occupied territories cannot speak Hebrew and many Jewish Israelis cannot speak Arabic." Hajjar, supra note 3, at 144 .

24. On the relationship between law and justice see Jacques Derrida, Force of Law: The "Mystical Foundation of Authority," II Cardozo L. Rev. 921, 95I (1990); Drucilla Cornell, The Philosophy of the Limit: Systems Theory and Feminist Legal Reform, in Deconstruction and the Possibility of Justice 68 (Drucilla Cornell et al. eds., 1992).

25. Criminal Procedure Law, 5742-1982, 36 LSI 35 (Isr.). 
translated into Hebrew by a translator, and then recorded in Hebrew into the trial protocol, "unless the court otherwise directs." 26 Furthermore, section I4I states that the content recorded by the protocol, which transforms the text from oral to written form, serves as "probable cause" for the content of the speech. Finally, section 142 determines that the court is obliged to fund the expenses of translation, unless explicitly deciding otherwise. The approach depicted by these few sections conforms to the United Nation's recommendations that "in all dealings with the state, the state will provide and pay for translation for any person." ${ }^{27}$ A similar legal situation prevails in large parts of the United States, where a federal statute, the 1978 Court Interpreters Act, provides the basic procedure of court translation. ${ }^{28}$ In both Israel and the United States, however, the state's obligation to provide translation in civil cases remains contested and unresolved. ${ }^{29}$

The translation services in Jerusalem are provided by a private company called "Protokol." Protokol also provides translation services to the various Israeli court systems, as well as to Israel's Ministry of Law and prosecution

26. Interestingly, while witnesses and various evidentiary artifacts that do not "speak" Hebrew must be translated by a court-appointed translator, this requirement does not apply to the translation of the defendant's testimony, which can also be translated by other court practitioners, the judge for example. See id. $\$$ I4I. The right of translation defined by section $14 \mathrm{I}$ is thus stronger than that defined by section 140 .

27. Francesco Capotorti, Study on the Rights of Persons Belonging to Ethnic, Religious, and Linguistic Minorities 96, para. 568 (1991).

28. Court Interpreters Act of 1978, Pub. L. No. 95-539, 92 Stat. 2040 (codified as amended at 28 U.S.C. $\$ \$ \mathrm{I}, 602-04,1827-28)$.

29. In his instructions of December 24, 200I, issued to the presidents of District, Magistrate and Labor Courts, District Court Judge Dan Arbel, Director of the Israeli Courts, required that parties to civil court disputes be charged when requesting translations of court proceedings and related materials from Hebrew to Arabic. This decision was widely contested by various state officials and non-governmental organizations, and was cancelled by Justice Arbel on Feburary 10, 2002. A year later, on February 10, 2003, Justice Arbel issued a new instruction restricting state-funded translation from Arabic to Hebrew only to those cases of clear necessity that leave the court with no other alternative. For a detailed description of this dynamic, see Adalah: The Legal Center for Arab Minority Rights in Israel, Adallah Organization to the Director of the Israeli Courts: The Judges Should Respect the Legislation That Establishes the Status of the Arab Language in the Courts, http://www.adalah.org/heb/pressreleases2003jul.php (July I5, 2003) (Hebrew); Adalah: The Legal Center for Arab Minority Rights in Israel, Adalah Demands That Courts Director Retract Translation Fee Instructions, http://www.adalah.org/eng/ pressreleases2002.php (January 7, 2002). 
units. ${ }^{30}$ At the time of the study, Gregor, the director of translation services for the Jerusalem court system, supervised approximately forty translators, fourteen of which were "regulars" and the rest temporary. ${ }^{31}$ The Jerusalem translators are of diverse age groups, ethnicity, gender, and place of origin. At the time of the study, not one had official legal education, and some had not even completed their high school education. Many of the translators are Palestinian-Israeli students, but there are also former policemen (usually of Mizrachi decent) and low-income women. Gregor is an exception: a ChristianArmenian, he completed his academic legal education in 1978 , and then worked as a translation contractor in the occupied territories. Since there are no formal criteria for selecting translators or for their training, Gregor practices a great deal of discretion in their hiring process.

Several informants indicate that most of the translation performed in the Jerusalem criminal court is between Arabic and Hebrew. Alongside Hebrew, Arabic is defined by Israeli law as an "official language." But while this definition has certain implications outside the space of the court, it does not seem to carry much weight (other than symbolic, perhaps) within the space of the criminal court. Within this space, Arabic is but one of many languages that the court is obliged to translate to Hebrew. ${ }^{32}$

The translators interviewed in this study point to three recurring challenges that they face in their everyday court practices: the dilemma between literal translation and what one of the informants has called spiritual translation; the difficulty of choosing between multiple meanings of words and phrases; and the translators' linguistic positioning when translating (specifically, their dilemma between using first or third person).

30. Protokol's website indicates that it is capable of providing translation for thirtythree languages. See Protokol, http://www.protokol.co.il (follow "English" hyperlink; then follow "Translation Services" hyperlink) (last visited February 9, 2007). Compare this with the twenty-seven languages used in federal district courts in the United States throughout 1986. See Berk-Seligson, supra note 4 , at 5 .

31. Interview with Gregor, Court-Appointed Translator, Jerusalem Criminal Trial Court, in Jerusalem (October, 2002). The translators were usually replaced at least every two years. The main reason for this transience was probably the translator's low salary (an equivalent of $\$ 4.50$ per hour).

32. For a thorough account of the official language system and for a critical analysis of Israel's legal "preference" of Arabic over other languages, Russian in particular, see Meital Pinto, On the Intrinsic Value of Arabic in Israel: Challenging Kymlicka on Language Rights, 20 Can. J.L. \& Juris. 143 (2007). See also HCJ 4112/99 Adallah et al. v. Tel-AvivJaffa Municipality et al. [2000] IsrSC 56(5) 393. 
Although these three challenges do not encompass the wide array of concerns that court-appointed translators face in their work, ${ }^{33}$ they nonetheless provide an opportunity for introducing the everyday practices of the translators interviewed as part of this study, and for exploring the work of translation from their own point of view. This exploration eventually undermines the assumption that the translators perform a technical role only, and suggests that translators introduce interrelational and informal legal practices that configure their everyday work in the space of the trial court.

\section{B. The First Linguistic Challenge: Literal vs. "Spiritual” Translation}

Berk-Seligson believes that the exercise of an appropriate level of literality is central to the work of the translator. ${ }^{34}$ Accordingly, she laments the "general lack of awareness on the part of most interpreters of the field of linguistics called "pragmatics," stating that professional interpreters "overwhelmingly view vocabulary as their number one linguistic problem. Problems of syntax and pragmatic scope are given slight attention, if any at all." 35 This is hardly the case demonstrated by the Jerusalem interviews.

Indeed, the primary challenge that the translators interviewed in this study are concerned with is whether to translate word-for-word or, rather, according to "the spirit of the words." The translators present a range of responses to this debate. Tova is an ultra-orthodox woman who has been working for several years as a translator in eight different courts (all part of the Jerusalem court system). ${ }^{36}$ According to Tova, "I translate like a log . . . . [T] he witnesses' intonations may go up and down, but I don't change my tone at all. Today

33. Some other examples include hyperformality, hedging, active versus passive voice, politeness in the courtroom, etc. See Berk-Seligson, supra note 4 .

34. Berk-Seligson refers to the court-appointed translator as an interpreter, which is also the term preferred in the American literature. See id. See also M.M.B., Witnesses: When Interpreters May Be Used, 24 Mich. L. Rev. 56 (1925). While the term interpreter highlights the agency of the translator, the term translator has a more technical connotation.

35. See Berk-Seligson, supra note 4, at 2. For an exploration of presentation styles in the courtroom see also John M. Conley, William M. O'Barr, \& Allan Lind, The Power of Language: Presentational Style in the Courtroom, I978 Duke L.J. 1375 (1978).

36. Tova was recruited to this job by her husband, who worked in the same office building as the Protokol company. After they accidentally found out that he is a fluent French speaker, the Protokol people suggested that he work for them in the Jerusalem court. He 
one of the four defendants collapsed. He started to cry during his testimony, telling the court how the incident [that was the subject of his trial] had ruined his life completely. But all along I didn't change my tone at all. ${ }^{{ }^{37}}$

Translator Tiki provides a different, perhaps even opposite, response to the debate between literal and "spiritual" translation. At the time of the study, translator Tiki has been working in various Jerusalem courts for over twelve years. She first learned about this position through an advertisement in the newspaper, applied, and passed what she describes as their very easy rest. Tiki explains how she translates. In her words, "I put all my emotions into the translation .... [S] omeone even told me that he felt like his words were coming out of my mouth instead of his, as if I were him, as if I was the person testifying. I am quite theatrical, and I think that that's crucial for bringing the words of the people to the hearts of the judges. ${ }^{38}$ At the time of his interview, Ali, a young Palestinian-Israeli student of economics at the Hebrew University of Jerusalem, has been working as a translator only two months. Ali agrees with Tiki's approach, adding what he describes as the harmful consequences of literal translation: "another thing I've learned . . o on my own," he stares, "is that I shouldn't translate word-for-word, because it just wouldn't be right for the meaning of the sentence. It is important to translate the meaning, not the words. If I translate the words, the defendant will really be lost." ${ }^{39}$

Clearly, the interviews with the translators support Berk-Seligson's claim that the level of literality has a crucial affect on the meaning-making process of translation. Yet despite its crucial effect, this aspect of court translation, like most other aspects, has remained unregulated by Israeli law. Consequently, the translators seem to randomly endorse conflicting practices, some translating "like a log," while others investing all their dramatic skills into the translation. Much can be said about the impossibility of regulating such personal tendencies. Furthermore, the multitude of translation practices could be depicted as a positive expression of the personified and vernacular faces of the law. At the same time, one might also

refused, but suggested that they contact his wife instead. This incident illustrates the lucidity and randomness of translator recruitment.

37. Interview with Tova, Court-Appointed Translator, Jerusalem Trial Court, in Jerusalem (June, 2002).

38. Interview with Tiki, Court-Appointed Translator, Jerusalem Trial Court, in Jerusalem (June, 2002).

39. Interview with Ali, supra note I. 
suggest that the random nature of these translation practices exposes the impracticability of the liberal ideas of equality and impartiality, supposedly applied at their best in and by the courts. The next subsection will discuss the second recurring challenge highlighted by the translators interviewed here. Specifically, it will further depict aspects of randomness in translation, explicating the fragility of words in the court setting.

\section{The Second Linguistic Challenge: \\ The Vernacular/Universalist Translator}

"Law," says Clifford Geertz, "is local knowledge; local not just as to place, time, class, and variety of issues, but as to accent-vernacular characterizations of what happens connected to vernacular imaginings of what can." 40 The second central challenge that the translators interviewed in this study have mentioned has to do with the multiplicity of local dialects in Israel/Palestine. This matter is presented by the following story told by Gideon, a former policeman and a Mizrachi Jew, who has been working as a translator in the Jerusalem trial court since 2000:

In my courtroom there was recently an issue over the [Arabic] word "baktul." Literally, this word means "to murder," so when the defendant said it, that's what I translated exactly. But his defense lawyer objected, arguing that the word means "to hit." I insisted, and meanwhile the judge understood that there's a controversy over the word. Although the protocol recorded only the word "murder," the judge has already understood."

Although from a different perspective, the same incident is also described by Rami, the Palestinian-Israeli lawyer that represented the defendant in this case, and whom I incidentally interviewed shortly after my interview with Gideon. Defense lawyer Rami explains that in the colloquial Arabic spoken in the region of Israel referred to as the Triangle, which is where both the defendant and his defense lawyer Rami are originally from, "bakutlak," Rami's variation on Gideon's "baktul," means "I will beat you" rather than "I will kill you." 42 Rami believes that the judge has based his

40. See Geertz, supra note 6, at 215 .

4I. Interview with Gideon, Court-Appointed Translator, Jerusalem Criminal Trial Court, in Jerusalem (October, 2002).

42. Interview with Rami, Defense Attorney, Private Practice, Jerusalem (October, 2002). 
finding of the defendant as guilty of murder on the confession allegedly made by the defendant when uttering the word "bakutlak" in the courtroom. Although Gideon and Rami disagree on whether or not the conviction was based on how the word "baktul" was translated (or the word "bakutlak" - even the dispured term is contested), this case explicates the possible stakes involved when the translators' practices take place within a criminal proceeding. Moreover, from the moment of its transcription into the court computer, the protocol becomes the official representation of what occurs in the courtroom. ${ }^{43}$ The decision to record only one version-that of the translator-into the protocol, without even a mention of the controversy over the most crucial word spoken throughout the trial, illustrates the strong powers exercised by the translators. In this instance, by its transcription into the trial protocol, translator Gideon's version of the court event is constructed as the true record of what really happened in the courtroom.

The controversy over how to translate the word "baktul" or "bakutlak" recalls another legal case that took place in a different geography: the trial of People vs. Fumiko Kimura. ${ }^{44}$ This trial, set in an American court, revolved around a claim for cultural protection made by a Japanese woman who was accused of murdering her two children. During the trial, the translator encountered a problem in translating the Japanese word "Oyaku-shinju," which means something between murder and suicide, and has no equivalent in the English language. While the Fumiko case highlights the inability of cultural translation due to the lack of suitable cognates for certain cultural meanings, the "bakutlak" event reveals the multiple meanings that different local dialects provide for the same word. In both cases, however, the stability of the word is contested through questioning its "correct" translation, rather than through recognizing the possibility that a word might carry a multitude of simultaneous meanings. The translator's insistence that only one translation of the word "baktul"

43. Austin Sarat discusses the relationship between history and memory as it manifests through the transcribed protocol. See Sarat, Rhetoric and Remembrance, supra note 12. Interestingly, the same company that administers translation services for the Israeli court system-Protokol-also provides the Jerusalem court with typing and transcription services. This labor nexus highlights the institutional and economic connection between the translators and the transcribers/typists--both considered relatively marginal in the hierarchy of court practitioners.

44. See Deborah Woo, The People v. Fumiko Kimura: But Which People? I7 Int'l J. Soc. L. 403 (1989). 
is possible exemplifies the desire of legal actors for obtaining a single, objective truth. Based on this translated truth, the court can then present a verdict of guilt in first degree murder as a scientific fact. ${ }^{45}$

\section{The Third Linguistic Challenge: Translating in First or Third Person}

The third and last challenge frequently mentioned by the informants is whether to translate in the first or in the third person. Translator Gideon, the former policeman mentioned earlier, presents a clear perspective on this issue: "I make sure to say 'he says that he'; otherwise it might seem as if I am the speaker, which is a lie." ${ }^{46}$ Translator Ali, the young PalestinianIsraeli student mentioned earlier, provides a different perspective on this issue. In his words, "the judge's typist is very nice and she corrected me. I used to say 'he says', but she explained to me that I should translate in the first person." 47

This debate illustrates the wide discretion practiced by the translators, as well as the scope of the informal norms that govern these practices. Indeed, since the translation process is largely unregulated by formal law, the translators fill in this lacuna with informal norms constituted through their everyday interactions with other court practitioners and users. It is for example the judge's typist/transcriber, rather than a more prominent Hermes-type court figure, that has informed Ali's translation practices.

The three challenges described by the translators demonstrate the varying levels of identification that exist between the translators and the subjects of their translation. How animated or literal their intonation should be and whether they should use the third person in their translation are both aspects of the debate over the optimal level of identification between the

45. Clifford Geertz's analysis of the fact/law problem might provide some insights into the question of translating dialects. Geertz alters the dialectic between "brute fact" and "considered judgment," between "what is so and what is right," and, in general, translates "the whole fact/law problem" into a "language of general coherence" and of "specific consequence." See Geertz, supra note 6, at 184 . In this context, Geertz portrays scientific law as "the nearest amenable and illuminating lie." Id. This corresponds with Geertz's general assertion that "[L]aw, here, there, or anywhere, is part of a distinctive manner of imagining the real." Id.

46. Interview with Gideon, supra note $4 \mathrm{I}$.

47. Interview with Ali, supra note I. 
person translating and the person who is being translated. The translator's choice between linguistic dialects is also a normative choice. Arguably, the translation of vernacular language should provide a sort of archeology of meaning intended to excavate the original speech act. Conversely, the act of translation could aspire to conjure other, perhaps more general, meanings of the word, which sacrifice the local for a unified, universal future. ${ }^{48}$

While this section focused on the task of translators as depicted through their own perspective, the following section will introduce the narratives of other court practitioners. Through an investigation of the relationships between translators, defense lawyers, and trial judges, section II will further explore what the informants describe as the translators' loyalties, on the one hand, and their performances of treason, on the other hand.

\section{BETWEEN LOYALTY AND TREASON: RETHINKING COURT ROLES THROUGH THE TRANSLATOR'S PRACTICES}

\section{A. The Translator's Loyalty towards Court Users:}

\section{A Betrayal of the Court}

What, in the informants' perception, is the primary loyalty of the translator? This question has triggered different responses from the informants. Police prosecutor Shachar initially insisted that the translator should not be loyal to any one side, but instead that "the translator has a double-folded taskwith his one eye he should be looking to the court and with his other eye to the defendant." ${ }^{49}$ However, Shachar eventually restates her position, saying that "there is no doubt in my mind that the translator's primary loyalty is towards the court." Initially, translator Tova tends to agree with prosecutor Shachar's first reaction, declaring that she does her work as if she is "from the UN." But after some reflection, Tova admits her "strong tendency to identify with the victims of criminal cases." In particular, Tova

48. Compare this notion of temporality with the discussion in Walter Benjamin, The Task of the Translator, in Illuminations 69, 70 (Hannah Arendt ed., Harry Zohn trans., 1999).

49. Interview with Shachar, Police Prosecutor, Israeli Police, in Jerusalem (October, 2002). Police prosecutors are authorized to prosecute offenses with a maximum seven-year sentence, while regional prosecutors are authorized to prosecute any crime. 
highlights her empathy towards "victims" of sexual offenses. Here, in her words, is how this empathy manifests in the courtroom setting:

It wasn't enough that this woman had to go through rape, she now also had to deal with the lawyer's threatening gazes. This woman was terrified: she was shaking like a leaf ["ale nidaf"]. So I spoke with her outside and told her that whatever happens, she should never look at the defendant or his lawyer, but only at me or at the judges. Then I placed my hand on her back and could feel her calming down. She realized that I was there with her and that she was not alone.

But Tova's acts of support for women witnesses in sexual offense cases goes beyond placing a hand on their back. When translating such proceedings, Tova admits that she intentionally tackles with words. In her own words:

I'll do anything to help these women, even if this means altering testimonies. .. . For example, I'll translate in such a way that would make the defendant's story sound more extreme so as to increase the chances of his conviction. Sometimes the defense lawyers realize what I'm up to, and then they start yelling and objecting. In this one case of a woman who was raped, I simply apologized and then proceeded with the translation.

Although the extent of this phenomenon might provide an interesting empirical exploration, whether Tova's alteration of testimonies is representative of the translation performed by most Jerusalemite translators is not the main concern of this article. As will soon become clear, other translators actually disagree with her approach quite strongly. However, Tova's narrative serves as yet another demonstration of the power available to the translators and the thin accountability practiced in this context.

Tova's agency is also a quintessential example of excessive governance: playing "out of order," ${ }^{50}$ especially as a state official, she exceeds the boundaries of her role, responsibility, and authority. Indeed, Tova is well aware that she pushes the rules of the legal game beyond the conventional norms, which is why, when caught, she immediately apologizes. Yet, she keeps on playing. Using her common sense and her familiarity with courtroom procedures, Tova knows all too well how to maneuver in and out of the formal legal framework. On the face of things, Tova's translation disrupts the crossexamination process, which assumes that an adversarial line of questioning

50. Davina Cooper, Governing Out of Order: Space, Law, and the Politics of Belonging (1998). 
exposes the truth. However, under certain circumstances Tova's act might actually be considered as informally strengthening the exposition of truth, or at least the notion of situational justice produced by the court, rather than disrupting or undermining it. Indeed, Sally Engle Merry suggests that "[a]s courts become more routinized and oriented to due process, they need to develop more informal procedures to provide a more individualized, situational and responsive process." $\$ 1$ Similarly, Susan Silbey asserts that situational justice is promoted by the efforts of state officials to provide justice within a legal context that does not really fit the problems at hand. ${ }^{52}$

Even Gregor, the director of Jerusalem's translation services, who usually adopts a strict and formal approach, conveys his shock at the aggressive cross examination of a seven year-old girl, and reacts by attempting to "fix" the problem through translation. In his words, "although she was raped, the lawyer asked her questions like 'how did he stick it into you,' just like that! Because I myself have children, I couldn't let her face him on her own, so I acted as a mediator between them." While the intentional distortions of the "original" meanings of words could be criticized on various grounds, it is also possible to interpret these translation instances by Tova and Gregor as acts of subversion to state law. The alienation of sexually assaulted women within court proceedings has been the focus of much criticism, and in certain instances state law was enacted -to address this issue. ${ }^{53}$ In this context, Tova and Gregor's practices might be interpreted as triggers for such institutional change. ${ }^{54}$ Through their informal, almost transparent, interventions, Tova and Gregor provide an alternative legal framework that reconstitutes law's humanness and thus also law's legitimacy. Although rarely perceived as exercising power over or within the macro rule of law, the translators nonetheless manage to influence the legal process through microscale practices of translation and interactive adaptations to formal law. ${ }^{55}$

If in the previous examples the translators have expressed their loyalty towards witnesses, and towards sexually assaulted witnesses in particular, the next two instances demonstrate the emotional loyalty established between

5I. Merry, supra note IO, at 259.

52. Silbey, supra note 9 .

53. See Conley \& O’Barr, supra note $\mathbf{1 8}$, at I5-38.

54. See Cooper, supra note 50, at 170.

55. See Marianne Constable, Reflections of Law as a Profession of Words, in Justice and Power in Sociolegal Studies I9, 22 (Bryant G. Garth \& Austin Sarat eds., I998); Austin 
the translator and the defendant. At times, this specific loyalty is exercised at the expense of the defendant's trust in his lawyer. Throughout his interview, Gregor emphasized that the most important factor in selecting translators is their familiarity with the law. He explained that "many times we function not only as translators but also as the defendants' attorneys." 56 This statement was also repeated, in variations, by most of the translators interviewed in this study. Translator Gideon describes, for example, that "even when the defendant's lawyer is in the room, when his lawyer is talking to the judge he sometimes turns to me to ask if I think he should confess. So I just tell him off, saying that I don't know anything; that I don't have any legal education." 57 Translator Tiki offers an economic explanation for this situation: "sometimes defendants can't afford to pay for attorneys," she says, "so I am the one that explains the legal arguments to them." ${ }^{8}$ Indeed, despite Gregor's explicit intentions, none of the translators interviewed in this study have had any formal legal education. Instead, they usually construct their knowledge of the legal system and of legalese-the term used by Berk-Seligson to refer to the legal language-through their everyday court experiences.

\section{B. The Translator's Loyalty towards the Court: A Betrayal of Court Users}

The previous subsection explored the translators' loyalty towards certain court users, either witnesses or defendants. Conversely, this subsection highlights the translators' role as officers of the court and their adversarial relationship with defense lawyers, which is often posed as a betrayal of the defendants.

Defense lawyer Guy started his legal career as a prosecutor in California. At the time of the interview, Guy was working as a criminal defense attorney in Jerusalem for over twenty years. Guy describes the court's attitude towards translation. In his words, "the court doesn't always insist on translation. ... [I]f the defense attorney knows Arabic, the judge will usually ask him to translate so that they don't need to spend time waiting for the translator." ${ }^{59}$ Guy perceives the process of replacing the translator

Sarat \& William L.F. Felstiner, Law and Social Relations: Vocabularies of Motive in Lawyer/Client Interaction, 22 Law \& Soc'y Rev. 737 (1988).

56. Interview with Gideon, supra note $4 \mathrm{I}$.

57. Id.

58. Interview with Tiki, supra note 38.

59. Interview with Guy, Defense Arrorney, Private Practice, in Jerusalem (July, 2002). 
with an Arabic-speaking defense lawyer as highly problematic. By turning the defense lawyer into a translator, he explains, the judge challenges the defense lawyer's primary loyalty towards his client, thus undermining the traditional legal roles necessary for due process. While in the example provided earlier the client was asking for advice from the translator rather than from his lawyer, thereby revealing the destabilized relationship between lawyer and client, in this last example the process of destabilization occurs through the judge's blurring of professional boundaries between translators and defense lawyers. In these two instances, the practice of translation exposes the fragility of the professional autonomy of both translators and defense lawyers.

Prosecutor Shachar and defense lawyer Rami add another perspective to the relationship between translators and defense lawyers. Through highlighting the role of translators as officers of the court, and thereby as integral participants in the criminalization process, the translators are also automatically portrayed as enemies of the defendants, while the act of translation is presented as a betrayal of the defendants by those who are supposed to speak on their behalf. Accordingly, here is how prosecutor Shachar describes the rensions between translators and defense lawyers:

Every other sentence that the defendant uttered and the translator translated was immediately contested and debated for long intervals of the hearing. This was all very embarrassing, both for Justice Freedman-Feldman and for myself. Since neither of us speaks a word of Arabic, we couldn't tell who was right. At a certain point I objected, arguing that this is no way to run a trial and that the attorney may submit his reservations to [Gregor]. ${ }^{60}$

Rami, the Palestinian-Israeli defense lawyer mentioned earlier, also depicts the adversarial relationship between defense lawyers and translators: "as a defense lawyer, I do my best to use the translation for my client's sake. That's why I think it's crucial that attorneys understand their clients' language directly." ${ }^{61}$ Defense lawyer Guy reinforces this position from the standpoint of someone who speaks only Hebrew and English: "everything goes through the translator, which weakens my level of control over the hearing, and, as a result, the quality of representation that I can provide for the defendant is also undermined." ${ }^{\prime 2}$

\footnotetext{
6o. Interview with Shachar, supra note 49.

61. Interview with Rami, supra note 42.

62. Interview with Guy, supra note 59.
} 
But defense lawyer Rami not only protects his client from inaccurate translation; he also actively uses the translation process as a vehicle for promoting his client's interests. By transforming his client's “impediment" of not speaking Hebrew to his advantage, defense lawyer Rami contests the formal legal system's positioning of power and powerlessness as dependant on the actor's knowledge of Hebrew. In his words: "[s]ometimes a client will hastily say something that could harm him, had the judge understood. So when the translator begins translating, I immediately start arguing and making a huge fuss ["balagan"]. Meanwhile, the defendant understands that he said something wrong, and when he is asked to repeat what he just said he corrects his mistake, and that's how it's finally recorded into the protocol." Rami further explains that although some defendants understand Hebrew, they frequently prefer to speak in Arabic so as to gain extra time for reconsidering their testimony. Similarly, defense lawyer Habib laughs when he describes how certain defendants, who present themselves as unable to speak Hebrew, suddenly start arguing with the translator in fluent Hebrew over the "correct" translation of what they just said in Arabic. ${ }^{64}$ This story demonstrates the negotiations of power that take place during the process of translation, which posit the translator and the defendant on opposite sides of the adversarial divide rather than on the same side, as was depicted by the previous subsection. Either way, the variety of instances presented in this section must also be read in light of the Israeli-Palestinian context, which is particularly complex in the Jerusalem setting. But before I move to discuss the particular spatial location of this study, the next subsection will examine the importance of translation in the eyes of the various informants.

\section{Does Translation Matter?}

The discussion whether to translate literally or "spiritually," in the first or third person, or by the translator, the defense lawyer, and even the judgeshares the underlying assumption that the act of translation, in whatever variation, actually makes a difference. ${ }^{65}$ However, the informants interviewed in this study are not necessarily in agreement over whether or not

63. Interview with Rami, supra note 42.

64. Interview with Habib, Defense Attorney, Privare Practice, in Jerusalem (October, 2002).

65. This is a fraction of the much larger debate on whether translation is actually possible. According to Walter Benjamin, translation would be possible only by importing from one language into another an entire fragment of foreign culture, and not just the 
translation matters. The following subsection explores this question from two perspectives: first, it focuses on the double-folded aspects of translation, emphasizing that the act of translation can move in two directions: from the defendant/witness through the translator to the judge; or the other way around - from the judge through the translator to the defendant/ witness. Secondly, this subsection also considers the importance of translation for the everyday functioning of the Jerusalem criminal trial court, as perceived by the informants.

Formally, the translator is expected to listen to the defendant, understand what he is saying, and, subsequently, translate this understanding into Hebrew for the court to hear, understand, and record through transcription. A similar translation process supposedly occurs in the opposite direction: by translating what the judge and the lawyer say for the defendant and witness to hear and to understand (yet without an official recording). Indeed, while state law assumes a two-way, symmetrical process of translation, the informants interviewed in this study depict an asymmetrical situation. According to the informants, when aimed at the defendants and the witnesses, the translation is only of secondary importance. How could this asymmetry in the way that translation is practiced be explained?

Underlying the liberal discourse applied by several of the informants are two interrelated assumptions: first, that translation is crucial for the defendants' right to due process; and second, that the court hearing is the key event in the production of scientific truth, and hence that the courtroom functions as this truth's central laboratory. However, in practice, the process of translation is mostly focused on the judge's knowledge of what is said by certain actors during the trial, while it is perceived as much less important to provide the defendant and the witness with similar knowledge. Hajjar's study of the Israeli military courts in the occupied territories identifies a similar tendency. Hajjar describes that "translators tended to consider that the only people who needed to understand what goes on in the courtroom are the judges, prosecutors and defense lawyers." ${ }^{66}$ But according to Hajjar, this assumption is not entirely misplaced, since the vast majority of cases are concluded through plea bargains rather than through trials. ${ }^{67}$ Notwithstanding, one might question

specific meaning. See Benjamin, supra note 48 , at 70-82. See also Hyland's discussion of Benjamin in Hyland, infra note ro5, at 1597.

66. Hajjar, supra note 3 , at 147 .

67. Id. 
whether such instrumental rationales should excuse this asymmetry and compromise the principle of due process.

Moreover, the asymmetry of translation practices challenges the equation of voice and speech with power and justice. According to Marianne Constable, since legitimate governance requires speech, liberal theorists have invented speech forums, for example by projecting speech into silence and naming it consent. ${ }^{68}$ However, although liberalism relies on the construction of "speaking subjects," power does not manifest solely through speech and translation. An example that Constable cites depicts a particular Indian chief's speech act as empty and mandatory, and as significant for its form and not for its content; the chief speaks to be heard and not to be listened to. Similarly, the courtroom setting, and the trial court setting in particular, can be conceived as a lab, where people with (black rather than white) robes talk for those who cannot speak, re-presenting their words for the purpose of "exposing" the truth. ${ }^{69}$ Both the law's implicit requirement of the defendant to choose speech rather than silence, and the rare, and mostly untranslated, occasions of speech by the judge exemplify that speech is a complicated thing that cannot simply be translated into a respective understanding of power. This corresponds with Hajjar's conclusion that

[t] ranslation . . . not only allows the functioning of the legal process to proceed but also serves to legitimize this system. . . . By enabling judges, prosecutors, and defense lawyers to understand one another and to communicate their points effectively, the translators contribute to maintaining an appearance of due process and an availability of legal rights for the defendants. ${ }^{70}$

The asymmetrical character of translation in general, and its specific manifestations in the Jerusalem criminal trial court in particular, are further articulated by the informants' comments on the importance of translation. Mostly, they tend to highlight the impact of translation on the criminal trial court judges, rather than on any other legal actors. For example, Guy, the experienced defense lawyer, describes the strong effects that translation

68. See Constable, supra note 55, at 3I.

69. Compare with notions of representation and translation introduced by Actor Network Theory. See, e.g., Michel Callon, Some Elements of a Sociology of Translation: Domestication of the Scallops and the Fisherman of St. Brieuc Bay, in Power, Action and Belief: A New Sociology of Knowledge? 196 (John Law ed., 1986).

70. See Hajjar, supra note 3 , at 144 . 
has on judges. In his words, "the translation has an incredible influence on judges. If the translator doesn't do his job right, what the judge is left with are just words, and that's a disaster for the defendant." "' Similarly, translator Tova (the ultra-orthodox woman who has been working as a translator for eight different courts) also stresses the importance of translation by highlighting its effect on judges. She says that "it's crucial that the judge understands the language, that's as clear as daylight. When the words come together with body language, it's obviously going to influence the judge. In the end of the day, he is human and so can also be moved by human emotions." ${ }^{22}$ Both Tova and Guy portray the judge as the center of the legal process. By reflecting and reinforcing the judge's centrality, their narratives illustrate the intricate ways in which the legal consciousness ${ }^{73}$ of various actors, and their distinctive ways of imagining the real, ${ }^{74}$ not only reflect but also shape this reality.

At the same time, both Guy and Tova's narratives clearly emphasize the informal dimension of the translation process. Rather than embracing the criminal statute's focus on words, they highlight the marginality of words and the importance of body. In their view, body language, rather than "word language," has the strongest influence over judges. By focusing on the judges' understanding of translation, these narratives reinforce the asymmetry of translation as practiced in the courtroom. Moreover, by highlighting the human nature of judges, translators Guy and Tova assume that they are as receptive as lay people to the non-linguistic signals utilized by defendants and witnesses. This commonsense perspective of the judges' humanness legitimizes the legal system, thereby increasing law's power in the ordering of knowledge.

Translator Tova further highlights the importance of translation through its significance for judges. She proudly lists several examples of content judges, explaining that

[r]he judges are pleased with my work, and that's because I translate very accurately. One of the judges was happy that I could tell that he understands the language--so he winked at me, while other judges write me blessings. Justice Ben-Dor even wrote me that he wants to thank me with

7I. Interview with Guy, supra note 59.

72. Interview with Tova, supra note 37.

73. Susan S. Silbey \& Patricia Ewick, The Common Place of Law: Stories of Popular Legal Consciousness (1988).

74. See Geertz, supra note 6, at 173. 
the only word he knows in French: "Merci." Justice Milanov apologized for not being able to make it to my son's wedding and sent a wired telegraph with greetings instead. And what do you think is the cause for all this? It's because the judges themselves understand exactly how important my work is. They understand that the more pleasant and calm the atmosphere in the courtroom is, that's how much more people feel that they can speak the truth, because they don't feel pressured. ${ }^{75}$

Tova's idea about the importance of her work as a translator is not confined to linguistics. Rather, she sees herself as an officer of the court, and, moreover, as an extension of the judge. Tova believes that the more pleasant the atmosphere in the courtroom is, the more truth telling will prevail there. What state law cannot regulate directly, the emotional constellation in the courtroom, for example, Tova fills in with her commonsense perception of the legal space of the courtroom. Yet Tova's narrative also hints that not only the judges' feelings but also the feelings of other courtroom participants make a difference. Defense lawyers Arie and Habib illustrate this point further.

I have argued that formal penal law stresses the importance of translation by assuming or imagining a reality in which translation makes a difference, and that this assumption is crucial for law's assertion of egalitarian justice. This reality is produced through the informants' imagination of translation as an important aspect of the judge's work. Before presenting the judges' own perceptions on the matter of translation, I will briefly introduce the position articulated by defense lawyers Arie and Habib. At the time of the interview, Arie was working as a defense lawyer for over fifteen years, mostly in the Juvenile criminal trial court in Jerusalem. He complains that "not one hearing goes by where there isn't one problem or another with the translation process. The judges just don't get it: they don't understand how important the translation is. It really affects the atmosphere in the courtroom: the defendant could feel that he is being heard."76

Habib is a Palestinian lawyer who has been working as a defense attorney for over thirty-two years. Habib further stresses the importance of court translation from the perspective of the defendant: "I don't know if [the translation process] effects the decisions of the judges or not. What I do know is that it definitely has an effect on how the defendant feels. 
When encountering a translator that doesn't do his job properly ..., he feels that he wasn't provided with a fair trial and that the legal system can't be trusted." By highlighting the procedural effects of translation on the defendant rather than its legal consequences on judges, both Arie and Habib set a preference for situational rather than formal justice. ${ }^{78}$ However, underlying this analysis is their assumption on the defendant's behalf that an appropriate technical procedure would inevitably result in a fair trial. Again, the defense lawyers' popular legal consciousness both reflects and reinforces the intrinsic interrelations between notions of formal and situational justice. One way or the other, both Arie and Habib's narratives bridge the gap between the non-judiciary persons' image of the importance of translation, on the one hand, and the judge's own perception of this issue, on the other hand.

After presenting what various court practitioners say about the importance of translation for them, it is interesting to describe what the judges themselves have to say on this matter. The judges interviewed in this study seem to question the importance of words in general and of the translation of words in particular, instead adopting the approach that truth can be found elsewhere, yet not in words. ${ }^{79}$ Justice Aurelia is a relatively young judge who has already worked in two different courts. She states upfront that in her view, "language is a minor thing [that] has no effect whatsoever on my decisions," and that "I have enough expertise to identify when someone is lying to me, with or without understanding the language that this person is speaking. The only thing the translation really does is to complicate things and to lengthen the hearings, nothing else." 80 Similarly, Justice Dan, an experienced trial court judge, states that "I have no problem with not knowing the defendant's language. . . I read his body language and I don't think I'm ever wrong with that. The fact that there's a translation process going on doesn't limit me in any way whatsoever."

77. Interview with Habib, supra note 64 .

78. On the distinction between formal and situational justice and their positioning as "dual ideologies of the courthouse" see Merry, supra note ro, at 258.

79. Formally, I interviewed two judges as part of this study. These judges agreed to the interview despite a general court policy that prohibits interviews. In addition, I conducted several informal conversations with judges on this matter.

8o. Interview with Justice Aurelia, Judge, Israeli Trial Courts of Various Locations, in Jerusalem (September, 2002).

8r. Interview with Justice Dan, Judge, Jerusalem Criminal Trial Court, in Jerusalem (September, 2002). In the notes I took during this interview I state the following: "the judge is 
Rather than highlighting its positive effects, both judges stress that translation practices carry no effect whatsoever on their work, and at times even have a negative effect on the length of the proceedings. While the judges' position stands in stark contrast to the importance that other informants, especially the translators, attach to the process of translation, they all share what is portrayed as the insignificance of words. Specifically, both judges trust that body language sufficiently provides them with an oracular ability to recognize the truth when they see it.

This is a peculiar perspective to be pronounced by judges - the actors most affiliated with the law. Their approach can be interpreted as a form of micro resistance to the formalities of state law, suggesting that they, too, act according to various systems of knowledge, perhaps even counterhegemonic ones. Of Constable's six possible meanings of law as a profession of words, ${ }^{82}$ the approach presented by the judges could be considered an illustration that law is not only a pretense of words but that it also involves the falseness of legal assertions of neutrality. In this particular context, while sections 140 to 142 of the 1965 Israeli Law of Criminal Procedure stress the importance of word translation, thereby highlighting law's depiction of the superiority of words rather than any other types of language, the judges' proclamations portray a different image of reality. Law's avowal of words is thus contrasted with the judges' less neutral, even irrational, modes of performance. The explanation of this discrepancy as an instance of the gap between the law in the books and the law in action is not sufficient in this context. The theme of universality, which is typically advanced by "gap studies," 83 cannot account for the complex realities constituted by court translation, which highlight the interpersonal and

looking at me with bewildered eyes. It seems as though he just cannot comprehend why I would choose such an insignificant and uninspiring topic like translation as the focus of my research."

82. These six meanings are: law as a sincere exchange of words, law as a commitment to speech, law as involving a falseness that belongs either to words or to the law insofar as it claims to be about words, law as a language, and the concern of speech with law. See Constable, supra note 55 , at 28 . The law-as-language formulation has been termed elsewhere as "lawyerese," and "legalese." On the former, see also Nancy W. Perry et al., When Lawyers Question Children, ig Law \& Hum. Behav. 609 (1995); on the latter, see BerkSeligson, supra note 4, at I4. According to Constable, only the sixth sense of law as a profession of words is not merely a call for power but also a direct call for justice.

83. See Bryant G. Garth \& Austin Sarat, Justice and Power in Law and Society Research: On the Contested Careers of Core Concepts, in Justice and Power in Sociolegal Studies I, 8 (Bryant G. Garth \& Austin Sarat eds., 1998). 
infrastructural interactions of the law. I suggest that by refusing to acknowledge the role of the translators for the meaning-making process of the law, the judges appropriate the task of translation, thus strengthening the mythical foundations of their powers. Ultimately, the process of translation illuminates the legal consciousness of judges and of other court practitioners and its intricate interactions with formal and informal law.

\section{PLACES OF TRANSLATION: \\ IN BETWEEN CONFLICT AND BELONGING}

[The lower courts] sit at the juncture of both the legal and political systems and therefore bear an extraordinary burden for monitoring and channeling demands for social change. ${ }^{84}$

[C]ourt translators work in a space where a variety of voices can and must be heard. ${ }^{85}$

I have asserted that the hybrid position of the translator in the Jerusalem court setting illuminates the hierarchy between traditional legal practitioners-judges, defendants, and lawyers. This assertion both challenges and reinforces the assumptions that lie at the core of legal order. Some of the informants have emphasized the notion of loyalty as it relates to the translator's practices: they align the translator with other court officials; on the one hand, while asserting his intrinsic connection to the court user (defendant or witness), on the other hand. As a result, the translator is simultaneously identified with, and intensely alienated from, the defendant.

The hybridity and liminality of the translator's role also manifests through the spatial dimension. The following section will explore such spatio-legal dimensions, hence advancing the understanding of legal space. The section is divided into two subsections. The first will focus on courtroom space, as well as on other, relatively neglected, court spaces, such as the space of the corridor outside the courtroom and the space of the courtroom outside the time of the hearing. The second subsection will discuss the somewhat wider spatial and temporal location in which this article is situared: Jerusalem, 2002.

84. See Silbey, supra note 9, at 16.

85. See Hajjar, supra note 3 , at 144 . 


\section{A. The Translator's Place in Court}

The particular tasks and roles of the translators are not only products of their institutional positioning, but are also manifestations of their physical loci within the space of the courthouse and the courtroom.$^{86}$ In Israeli courts, including the Jerusalem trial court examined here, the translators are corporally present in the courtroom, rather than located in another place or behind a shaded glass. ${ }^{87}$ Since the defendants and witnesses usually testify from a stand, the translators are, for the most part, the only persons permitted to stand near them during their testimony. The physical intimacy between the translators and the defendants (and other witnesses for that matter) during the legal event is meaningful: it contributes to the level of intimacy established in the courtroom and explains some of the occurrences discussed in the previous sections, such as notions of loyalty and trust between the translator and the witness/defendant. ${ }^{88}$ But the physical proximity between the translators and the defendants is not limited to the traditional scene of the legal event, namely that of the courtroom trial. The translators' practices also push the boundaries constituted by the formal legal discourse between the courtroom itself and other court geographies, the court corridor for instance.

Translator Tova explains, for example, that since she finds it crucial to understand the "subject of translation" during the hearing, she prefers to

86. The Jerusalem trial courthouse is relatively old and has been poorly maintained. Inside the small court rooms, the judges and typists are siruated on a heightened podium, a computer facing each of them, while on the ground level two tables are usually posited on opposite sides of the room, with several benches in berween. The translation office is located in a marginal section in the courthouse, and is quite neglected in its appearance. In fact, the one room assigned to translation services is so small that it can hardly be considered an office. Only someone that knows her way around could in fact find this room on the third and last floor of the old courthouse, which is marked by no signs, and furnished by nothing but three chairs and two desks that fill the entire room completely.

87. Both in Israel and in the United States, the protected form of translation is usually limited to indoor court setrings, while out-of-court practices, the best example of which is the meeting between lawyer and client, are mostly not recognized as protected cranslation sites, and, accordingly, are nor funded by the state.

88. And, alternatively, towards the court. Indeed, in many of the trials that I have observed, the translator and the judge, having spent so many hours together, develop a certain familiarity between them. For example, in one of the participatory observations Gregor and the judge discussed intimate family matters as they were waiting for the next defendant. 
start exercising this understanding already before the hearing. In her words, "I almost always approach the subject of translation while he is wairing in the corridor before the hearing. ${ }^{\text {"g9 }}$ By doing so, Tova intends to both "figure out the nuances of the witnesses' pronunciation" and to "make these people trust [me] more." ${ }^{.0}$ This practice provides the translator access to certain knowledge, as illustrated by the following story, told by Tova:

Last week I had a witness who spoke Yiddish. When I spoke to him before the trial I learned that he is also deaf, but that he can read lips. The defense lawyer, who was appointed to represent him just several hours earlier, was totally unaware of this [condition]. The judge was extremely grateful that I pointed this out, and everybody turned to the witness so that he could read their lips."

However, the successful outcome of Tova's informal out-of-the-courtroom practice is hardly the end of the corridor story. Gregor, the director of translation services in Jerusalem, had entered a heated debate with Tova precisely over this question, his approach being that "talking with the defendant before the trial compromises [the translator's] neutrality." Gregor's approach corresponds with his overall definition of a good translator as someone who "should not identify with the defendant, [but rather] should be like a machine," depicting the translator as an impartial vessel that is expected to replicate rather than transform what is being said. ${ }^{93}$ While Gregor's approach is not grounded in formal regulations any more than Tova's, it is also not arbitrary or incidental. From a certain perspective-Gregor's, for example-Tova's interactions with the defendant outside the space of the courtroom violate a central legal principle, that of impartiality. It also challenges the formal legal discourse that regards the courtroom as the central stage of the legal event. But while the translator's practices are mostly unregulated by state law, the translator still acts within legal frameworks of ordering, albeit unofficial ones. Hence, while the normative ordering that Gregor exercises in this case is

89. Interview with Tova, supra note 37 .

9o. Id.

9I. Id.

92. Interview with Gregor, supra note 31.

93. Id. 
based on a replication of certain aspects of state law, Tova's practice might be interpreted as utilizing an oppositional form of ordering, one that challenges state law by fusing commonsense knowledge into the informal court proceedings.

The mini-controversy between Tova and Gregor is over a specific, liminal geo-legal space: the corridor space just outside the court room. The classification of a space as outside or inside the courtroom triggers the application of different norms. When inside, the translators are not only allowed but are also encouraged to talk with defendants and witnesses, yet when several steps away, this practice is contested. A similar challenge is presented by police prosecutor Shachar in relation to another liminal space of the law: inside the courtroom yet outside the temporal setting of the specific trial. While initially Shachar states that "the translation system is completely fine," as an afterthought she adds that the only problem with the defendant's inability to speak Hebrew occurs "during the waiting period that precedes his own trial." ${ }^{94}$ This period is important, in her view, because it provides the defendant with "some perspective, some comparison for the working of justice, which is prevented from him when he doesn't understand what's going on."95 Hence, while Shachar refuses to acknowledge the role of language in determining power relations within the traditional legal space of the courtroom, she admits its significance in the "out-of-trial" setting. Ultimately, Shachar, too, acknowledges the randomness of law and the limits of its rational application.

Exemplifying the everyday practices of translation in and out of courtroom space and trial temporality, the instances presented throughout this subsection further demonstrate the challenges that translators pose to the traditional legal roles and to the status of the hearing as the major temporal legal event.

\section{B. The Place and Time of Translation: Jerusalem, 2002}

It is through translators' particular mode of service to the state and the importance of that service in legitimizing the occupation, that these contradictions can be seen not as an oversight but as an imperative of Israeli state rule over "non-Jewish" populations on both sides of the Green Line. ${ }^{96}$

94. Interview with Shachar, supra note 49.

95. Id.

96. See Hajjar, supra note 3, at 153 . 
The Jerusalem trial court is situated only a few meters away from the Green Line. ${ }^{97}$ This location is significant both physically and symbolically. In particular, Jerusalem's criminal trial court challenges the distinctions between "inside" and "outside" the State of Israel, thus highlighting the place of this court as a border zone. ${ }^{98}$

This subsection will focus on an aspect referred to only briefly in the previous secrions: the political and ethnic identity of various court actors, and translators in particular. Although many languages are spoken in the Jerusalem trial court, Arabic has a unique position, both in Israel generally and in the Jerusalem court setting in particular. At the time of the study, most of the translators in the Jerusalem criminal trial court were translating between Arabic and Hebrew, and a large number of defendants, probably the majority, spoke Arabic as their "native" language. Alongside Hebrew, Arabic is defined by the Israeli law as an official language and, as such, holds a special status among the numerous languages spoken in Israel. But although governmental institutions are obliged by law to use Arabic in public spaces alongside Hebrew, ${ }^{99}$ at the time of the study no "native" Arabic speakers were to be found either among Jerusalem's trial court judges or among most of the Jerusalem prosecutors. ${ }^{100}$ Consequently, the language spoken by court officials is almost exclusively Hebrew, while the language spoken by most of the Jerusalemite defendants consists of various dialects of Palestinian Arabic.

According to Hajjar, "the Jewish/Arab dichotomy is reinforced linguistically: language differences coincide with the political distinctions between occupier and occupied." ${ }^{101}$ Indeed, in an attempt to distinguish itself from its diasporic origin, the Zionist narrative "revived" the Hebrew language, making it into a central theme in the formation of the Zionist nation-state. In particular, Jewish Israelis usually take pride in their distinct Hebrew accent and preserve it as a central signifier of their national

97. The Green Line was the border between Jordan and Israel from 1948 to 1967, and still occupies a significant place within the national agendas of both Palestinians and Israelis.

98. See also Hajjar, supra note 3 , at I53.

99. See HCJ 4II2/99 Adallah et al. v. Tel-Aviv-Jaffa Municipality et al. [2000] IsrSC 56(5) 393 (referring to the relations between Arabic and Hebrew on public street signs).

100. Some states have introduced specific laws to prevent such a situation, mandating a quantitative correspondence between the percentage of judges from a certain ethnic minority and the percentage of this minority in the general population.

IOI. See Hajjar, supra note 3, at 133. 
identity, inside Israel ${ }^{102}$ as well as abroad. The strong correlation between "native" Hebrew-speaking capabilities and the supposed affinity with the Zionist national cause is also used to eradicate the inner fragmentation that exists among Israeli Jews, for example between Russian- and Hebrewspeaking groups. ${ }^{103}$ Yet the unification around Hebrew as the hegemonic national language also triggers counter hegemonic acts, such as in the case of the Arabic-speaking Palestinian. ${ }^{104}$

Unlike the Hebrew language, which was created rapidly and top-down, "Arabic" is a generic term for many dialects. Consequently, various Arabic speakers are sometimes unable to understand each other. Simultaneously, the differences between the Arabic-Palestinian dialects are being constantly eroded, mainly through the attempt to construct a unified Palestinian identity with a national authenticity that would counteract the Jewish Israeli one. In a way, this homogenizing process of Arabic's richness and plurality undermines the diversity and inner strength of Palestinian sociality. ${ }^{105}$ Hence, the (counter hegemonic) process of linguistic unification carries a potential for a (hegemonic) fragmentation.

The linguistic Hebrew-Arabic conflict also translates into the particular place of the Jerusalem criminal trial court. When testifying in the Israeli courts, a Palestinian has several options: he can refuse to speak, decide to speak in Arabic and have his speech translated, or speak Arabic and refuse translation. Finally, he also has the option of speaking in Hebrew. But although

I02. For example, security guards situated at the entrances of most public places in Israel are expected to identify those who pose a security risk. One of the main techniques for doing so is by asking the "suspect" a mundane question, listening to his response, and in turn distinguishing the level of "Hebrewness" in his accent. This implies that any nonnative speaker is considered a security risk. Policing through language thus provides a tool for the promotion of spatial exclusion.

I03. For a discussion of the legal relationship between Russian and Arabic, see Pinto, supra note 32.

104. On the imperfect transmissions of hegemonic value and on law's "moving hegemony," see Alan Hunt, The Ideology of Law: Advances and Problems in Recent Applications of the Concept of Ideology to the Analysis of Law, I9 Law \& Soc'y Rev. II (1985); Trubek \& Esser, supra note I5; Sarat \& Simon, supra note 17, at 20.

IO5. This approach is advanced by Richard Hyland, who portrays the biblical story of the Tower of Babel as a positive multicultural event: "If humanity were possessed of but a single language, it would inevitably believe that there is but a single, valid understanding. . . [T] he confusion of language, by making it difficult for one nation to communicate with the next, permitted each group to develop relatively autonomously the possibilities it received." See Richard Hyland, Babel: A Sheur, II Cardozo L. Rev. I585 (1990). 
many of them know Hebrew, Palestinian defendants often refuse to speak it. Their refusal is not only pragmatic (as a tactic for gaining time, for example) but is also an act of resistance. The Hebrew language is perceived by Palestinians, especially those that reside in the occupied territories, not only as the language of a colonizer but also as the language of a military occupier, which is used to threaten their physical, cultural, and national survival. The realization of the language's national powers corresponds with certain studies that illustrate how the survival of political minorities in multinational states depends on the survival of their language. ${ }^{106}$ Other studies highlight "native" language as the central element of individual identity. ${ }^{107}$ Either way, the "ideology of native-language-and-identity" ${ }^{108}$ makes a direct correlation between mother tongue and nationhood, explaining how the refusal to speak Hebrew can be considered a (national) act of resistance to the Israeli state. ${ }^{109}$

The geographic location of this study is significant for understanding the legal and political role performed by the Jerusalem court and for making sense of the everyday working of law in this specific spatial constellation. ${ }^{10}$ During the Second Intifada, the role of Jerusalem as a city that connects the southern West Bank to its northern parts increased. Moreover, because of its proximity to both areas of the West Bank, and due to the economic opportunities available in this location, Jerusalem has become a central daily destination for many Palestinian workers.

I06. See, e.g., Adeno Addis, Cultural Integrity and Political Unity: The Politics of Language in Multilingual States, 33 Ariz. St. L.J. 719 (2001).

107. See Joshua A. Fishman, Language and Nationalism: Two Integrative Essays (1972).

108. See, e.g., John Myhill, The Native Speaker, Identity, and the Authenticity Hierarchy, 25 Language Sci. 77 (2003).

109. However, the "native speaker" concept is highly problematic. See, e.g., Alan Davies, The Native Speaker in Applied Linguistics (1991). This is especially true when this concept is perceived as a matter of scientific facts rather than as a social construction. Also, macrolinguistics disagrees about whether the loss of ancestral language is necessarily connecred with the loss of ethnic distinctiveness. Some point out, for example, that certain cultural collectives have survived despite not having a common language (Jews and Romans for example). See, e.g., Myhill, supra note 108, at 78.

IIO. The temporal constellation is highly important as well: almost two years after the start of the Second Intifada in October 200o, the scale of violence in Israel and in the occupied territories increased to new levels. Specifically, in May 2002 the Israeli Defense Force launched what it called "Operation Defense Shield" in the Jenin refugee camp. Incidentally, this was also precisely when I started my interviews and field observations. At the time, I was not fully aware of the possibility that this intense political situation might have some influence on my study in Jerusalem. 
Specifically, Palestinians crossed the border into Jerusalem to find work. As a result, a growing number of criminal charges were initiated by the Israeli police and prosecution against Palestinians, mostly for violating the 1952 Entry into Israel Law that defines those who enter Israel without a permit as "illegal aliens."

The court rulings of the period reflect and respond to this situation. In 2002, the Israeli Supreme Court decided that it was reasonable to keep "illegal aliens" under custody for the entire duration of their trial," which could last months or even years. Framing this decision as a legal precedent, the lower courts incarcerated many of the Palestinians charged under the "illegal aliens" policy for the entire duration of their trial. In this context, the lower court functions not only as a juncture between the legal and the political, as illustrated in the quotation from Susan Silbey presented at the outset of this section, but also as a place where criminal proceedings are utilized for the advancement of specific ethno-national ideologies. ${ }^{112}$

Such ethno-national ideologies lurk at the core of the structural hierarchy of the translation system itself. I have already mentioned that Gregor, the director of the translation services in Jerusalem at the time of the study, is Armenian. This information could help to explain why he is the highest ranking translation official in the Jerusalem court system. Although they are Arabic-speakers, the Armenians tend to live in isolated enclaves, and usually do not consider themselves Palestinian. In this sense, Gregor's Armenian identity challenges the dichotomized configuration of the Palestinian/ Israeli ethno-national split. Similarly, Hajjar highlights the role of the Druze as army translators in the Israeli military court system. The Druze, she points out, are "non-Arab Arabs in a Jewish state engaged in an ongoing conflict with Arab enemies." 113 Indeed, perhaps because of his Armenian identity, the Israeli court system trusts Gregor to exercise a leading role in the management of the court's official translation service. When performed by this intermediary figure, the translation event is legitimized, thereby assisting to reinforce Israel's juridical control over the Palestinians. Another important dialectic identity that is constructed and

III. CrimA 2739/02 Sabach v. the State of Israel [2002] IsrSC 56(3) 92.

I12. Acknowledging this situation, Hajjar states that "[ $t$ ]he courtrooms are staging grounds for broader struggles, and the legal process can serve as one form or forum of political engagement." Hajjar, supra note 3, at $\mathbf{1 4 5}$. Cf. Silbey, supra note 9.

II3. Hajjar, supra note 3, at 152 . 
reinforced in this context is that of the Palestinian-Israeli translator. I will explore this identity through the narrative of translator Ali.

$\mathrm{Ali}$, a young Palestinian Israeli, describes his particular situation as a translator:

It's true that at first I identified with the Palestinian defendants. As fathers to five or six children, what else could they do other than do their best to feed their family? So they have attempted to enter Israel for a day's work and then they got caught. But the judges totally misunderstand what's going on. They see everything through the lens of the Israeli media. So they end up throwing them in jail for six months. Now how do they expect this family to survive? At first it tore my heart apart to see this stuff, but then what could I do? Nothing. And now, even when the defendants or detainees ask for my help, I tell them that I can't do anything, because if I do I'll find myself without a job. So I never talk to them, not before the trial and not afterwards, and I do my best to feel nothing. ... I can't have any sentiments. ${ }^{114}$

Although Ali is careful not to blame the Jerusalemite judges or the Israeli court system, but only the Israeli media, he nevertheless acknowledges the political nature of such court miscommunications. At the same time, unlike Tova's intentional and ideological transformation of words, Ali avoids the active use of translation as an explicitly ideological vehicle. Instead, he attempts to "do his job" in the most narrowly defined, emotionally remote way, avoiding interactions that might take place outside the formal courtroom setting.

Ali's refusal to make use of his local, commonsense knowledge of the complexity of the situation serves to reinforce the hegemony of the Israeli court system. Insecure in his own survival in this system ("I'll find myself without a job"), Ali presents himself as powerless against it. Accordingly, far from non-ideological, Ali's translation strategy can be interpreted as an (ideological) statement of alienation. However, neither his alienation nor his powerlessness are absolute. As a speaker he silences others to talk in their name. ${ }^{15}$ At the same time, the act of translation also subjects Ali to the process of silencing and marginalization by other court practitioners.

II4. Interview with Ali, supra note I.

II5. According to Michel Callon, translation is what actors do when things cannot speak on their own; it is a process of representation. Callon (and Actor Network Theory in general) is particularly interested in the process of translation that presents itself as scientific, and especially when scientists speak for nonhumans. See Callon, supra note 69, at 196. 
His identity as a Palestinian Israeli is a split identity. Indeed, expected to constantly prove their loyalty to both "sides" of the conflict, Palestinian Israelis in general assume submissive as well as subversive roles towards both parties at the same time. Put differently, "translators who work in such an environment become the mouthpieces of authority and resistance." 116

More generally, Hajjar argues that the bilingual Hebrew-Arabic speakers challenge the national dichotomy constructed in Israel/Palestine. Utilizing their position as translators, Hajjar continues, Mizrachi Jews, Druze, and "Arab citizens of Israel" contest the Zionist theme." Although I agree with Hajjar that the translators are usually acutely attuned to the hegemonic aspects of the Israeli court system, Ali's narrative suggests that the specific constellation in the Jerusalem court can also result in the erosion of the subversive potential vested in the act of translation. In other words, it might disempower Palestinian Israeli translators rather than provide them grounds for everyday acts of resistance. Indeed, in certain circumstances the act of translation turns into a disciplining mechanism of submission to Israel's hegemonic legal apparatus.

Interestingly, the translators interviewed in this study have mostly been reluctant to acknowledge the ideological dimensions of their work. For example, most of them see the relationship between Arabic and Hebrew as only technical. Specifically, several of the translators define the terms of the debate over their identity as revolving around whether a translator should be a "native-speaker in the destination language" or in the "language of origin." Again, although on the face of things the translation process might seem two-sided and symmetrical, the informants clearly consider the translation event as originating in the speech of actors not affiliated with the court system, namely the defendants and witnesses (defined, respectively, as speaking the "language of origin"), rather than the speech of judges and lawyers (the "destination language"). Put differently, it is considered less important for the subject of the legal proceeding to understand the legal event than it is for court officials, and judges in particular, to understand what the legal subject is saying.

Accordingly, Oded, a defense attorney at the time of the interview, believes that "the unwritten rule of professional translation is that the translator should have more control over the destination language than

II6. See Hajjar, supra note 3 , at 145 .

1I7. Id. at I34. 
over the language of origin." 118 However, most of the informants have taken the opposite approach, asserting that fluency in the "language of origin" is the translator's most important skill. The decision whether to hire translators who are more fluent in the "language of origin" or in the "destination language" indirectly determines the specific ethnic identity of these translators. Gregor states, for example, that "from my translators to and from Arabic there is only one Jew and the rest are Arabs, because Jews usually learn Arabic in the army and that's not so good for the oral stuff." 19 By configuring the debate as merely linguistic, the informants conceal the political elements that underlie the decision over the translator's identity, thereby legitimizing it. Since the defendants are mostly Palestinian, and the judges in the Jerusalem trial court are all Jewish Israelis-the ethno-political identity is very much reflected in the court's hierarchy.

\section{CONCLUSION}

Although dealing with law's most sacred object — words ${ }^{120}$ — the working of the court-appointed translators, their tasks and practices, identities and loyalties, have largely gone unnoticed in sociolegal studies. Perhaps because their role is perceived as highly technical, not much legal attention in general has been devoted to the translators' function in the courtroom, which is treated as incidental at best. It should not come as a surprise, then, that the task of the translators is also scarcely regulated by Israeli law. The study of court-appointed translators is therefore an exploration into the informal norms that govern the courtroom space, and the space of the Jerusalem trial court in particular.

When asked about the everyday challenges they face in the Jerusalem criminal trial court, the translators emphasized three specific dilemmas. These dilemmas served as the focus of the first part of the article (section I). Specifically, the translators found it difficult to decide between literal and 2002).

I18. Interview with Oded, Defense Attorney, Private Practice, in Jerusalem (October,

II9. Interview with Gregor, supra note 3I.

I20. See David Delaney, Beyond the Word: Law As a Thing of this World, in Law and Geography 67 (Jane Holder \& Carolyn Harrison eds., 2003); see also Constable, supra note 55 . 
"spiritual" translation, between translation in the third or first person, and on how to translate linguistic dialects. At first, these three challenges seemed to support the view that the work of translation is highly technical. Yet a closer exploration revealed that these challenges require the translators' normative judgment, in turn inspiring a legal mini-drama that invokes strong notions of loyalty and treason.

The second part of the article (section II) constructs an image of the translator as a mediator between wor(l)ds. Positioned at the nexus between court practitioners and court users, the translator mediates not only between the languages of different legal actors, but also between their cultures and ideologies. However, toward the end of this second part a more skeptical tone is introduced, questioning whether the act of translation by the court-appointed translator actually matters. Recalling the scene of the contested translation of the vernacular word "bakutlak," or that of Tova's innovative translation/transformation of testimonies in the rape-victim example, one might infer that in the legal setting words do matter. These instances also seem to support the realization that either when uttered or when silenced in the courtroom, words promote certain ideologies, either gender oriented, such as translator Tova's agenda, or ethno-national, such as Ali's refraining from actively participating in the negotiation of legal meaning.

Conversely, the judges question the very need for a word-for-word translation. By asserting their knowledge of the truth without deeming it necessary to understand the specific words uttered by court users, the judges reveal the assumptions of omnipotent power that lie at the core of the trial court, the most ubiquitous of all legal settings. Furthermore, I established that despite its formal definition as a two-sided process, the practice of translation is in fact mostly oriented towards one side, that of the professionals that run the trial, rather than for the laypersons who use the court. Translation, according to my line of argument, is thus a façade for disguising the omnipotent and oppressive working of state law. Indeed, operating by influencing modes of thought as well as modes of conduct, formal state law, through translation, "shapes consciousness and makes asymmetries of power seem ... natural and benign."

But the translators also subvert this hegemonic process. By undermining the place of law as centered in the courtroom at the time of the trial,

12I. See Sarat \& Simon, supra note 17 , at 19. 
the translators offer an understanding of "third spaces": those ordinary locations where laypersons negotiate traditional legal assumptions. Such, for example, is the place of the courtroom corridor, where court translators interact with court users just a step away from the looming control of the father figures of formal law.

Accordingly, the third part of the article (section III) focused on the space of law as illuminated by the identities and tasks of the translators. Zooming out from the corridor space, the particular urban and national location of the Jerusalem criminal courtroom at the time of the study determines the everyday practices of the translators as highly political. Indeed, through this study of the specific linguistic roles and interactions that take place in the criminal trial courtroom, Jerusalem's specific role as a border city also emerges. It is hardly incidental, for instance, that most of the Jerusalem judges speak only Hebrew, while many of the defendants only speak Arabic. Within this particular spatial constellation, the translators perform a distinct role: they mediate and transform cultures. However, as Ali's narrative suggests, their identity is also challenged and molded by this process. Shifting between courtroom locations, the translator is a hybrid, a "non-professional professional" as well as a "non-Palestinian Palestinian." In this context, both the appointment of an Armenian as director of the Jerusalem translation services, and the use of Palestinian Israelis as soldier-translators demonstrate the force of law exercised by the Jerusalem-based trial court. Whether ultimately the translators serve primarily to legitimize or subvert such a project of law enforcement depends on the place of translation. 